\title{
Effects of temperature on the surface and subsurface of Al-Mg-Si welded joints
}

\section{Muhamad Hellmy Hussin ${ }^{1}$ and Nur Azida Che Lah ${ }^{1}$}

\author{
${ }^{1}$ Fabrication and Joining Section, Universiti Kuala Lumpur Malaysia France Institute \\ (UNIKL MFI), Seksyen 14, Jalan Teras Jernang, \\ 43650 Bandar Baru Bangi, Selangor, Malaysia \\ *Email: hellmy@unikl.edu.my \\ Phone: +603 8913800; Fax: +603 89258845
}

\begin{abstract}
Al-Mg-Si (6061) Al alloy represents a widely used light material which is highly dependent on the distribution of its alloying element. Yet, when it involved a welded structure, the performance was absolutely dissimilar due to the influence of alloying element from filler metal addition, especially when it is subjected to high temperature environment. Thus, the study focuses on the surface and subsurface oxide growth patterns, its morphologies, and phases that formed after oxidation exposure. The plates were joined by GMAW using Al-5\% Mg (ER5356) filler metal, and then subjected to an oxidation process in air environment at $400{ }^{\circ} \mathrm{C}, 500{ }^{\circ} \mathrm{C}$ and $600{ }^{\circ} \mathrm{C}$ for $40 \mathrm{~h}$; their mass gains were then measured. The oxidised parent and fused metal parts were subsequently analysed using the scanning electron microscopy (SEM), energy-dispersive X-ray spectroscopy (EDS), and X-ray diffraction technique (XRD). It was observed that with the increasing temperature, the fused metal parts exhibited different oxide morphologies on both surface and subsurface compared to the parent metal parts. Additionally, the less oxidation attack was found after exposure at $400{ }^{\circ} \mathrm{C}$ and poor oxidation behaviour showed at 500 and $600{ }^{\circ} \mathrm{C}$. The $\delta-\mathrm{Al}_{2} \mathrm{O}_{3}$ phase was detected in both parent and fused metal samples after exposure at 400, 500, and $600{ }^{\circ} \mathrm{C}$. Meanwhile, contradicted observation showed that the $\mathrm{MgO}$ phase was detected in fused metal part responsible for the poor oxidation behaviour. Thus, this would lead to a formation of non-protective oxide on the fused metal surfaces. This study suggested that the 6061 welded structure can withstand at $400{ }^{\circ} \mathrm{C}$ for long periods in air without serious deterioration but could not withstand exposure to 500 and $600{ }^{\circ} \mathrm{C}$ conditions in air.
\end{abstract}

Keywords: Al welded joint; high temperature; surface; subsurface; oxide growth.

\section{INTRODUCTION}

Alloys of $\mathrm{Al}, \mathrm{Mg}$, and $\mathrm{Si}$ (6061 Al alloys) are important for a variety of applications such as truck and marine components, cars, tank fittings, and high-pressure general structural components. These alloys have excellent corrosion resistance, formability, and weldability [1-5]. Additionally, these alloys are desirable for making components of internal combustion engines such as the cylinder block and head and piston, which are usually subjected to relatively high temperatures during service [6]. These alloys develop excellent corrosion resistance at room temperature because of the formation of a surface passivation layer of $\mathrm{Al}_{2} \mathrm{O}_{3}$. Besides that, these alloys are usually subjected to artificial aging to obtain an increased strength and it shows that these materials are highly 
dependent on the distribution of its alloying element [7]. In technical applications, $\mathrm{Al}$ is alloyed typically with $\mathrm{Mg}, \mathrm{Zn}, \mathrm{Cu}$, or $\mathrm{Fe}$ [8-10]. These alloys greatly increased strength but have significantly decreased corrosion resistance. The susceptibility of oxidation is often linked to $\mathrm{Mg}$ content, which can increase the strength of the alloy but is detrimental when the alloy is in an oxygen-containing environment at elevated temperatures. In some cases as stated by Eskin et al. [7], Al-Mg-Si that contains an excess and the precipitation of $\mathrm{Si}$ and the change in the $\mathrm{Mg}-\mathrm{Si}$ ratio during precipitation kinetics is significantly important. As reported by Kim et al. [11], the Al alloy that consists of Al matrix and a small amount of $\mathrm{Mg}-\mathrm{Si}$ precipitation and $(\mathrm{Co}, \mathrm{Ni})$ strengthening particles show an increase in elongation. It was also reported that the limit of the low-cycle fatigue showed superior value of plastic strain amplitude. Despite that, Stadler et al. [12] discussed the influence of $\mathrm{Ni}, \mathrm{Cu}$, and $\mathrm{Mg}$ on the high temperature strength and found that these alloying elements enhance the alloy strength by various strengthening mechanisms. One of their results showed that $\mathrm{Cu}$ and $\mathrm{Mg}$ improve the thermal stability because of the precipitation of the secondary phases which are $\mathrm{Al}_{2} \mathrm{Cu}$ and $\mathrm{Mg}_{2} \mathrm{Si}$ [13]. Meanwhile, an independent addition of $\mathrm{Ni}, \mathrm{Cu}$, and $\mathrm{Mg}$ improve the strength, especially at elevated temperature. An addition of $\mathrm{Mg}$ provides and improves the hardening characteristics of $\mathrm{Al}$, and imparts good corrosion resistance [14].

In essence, the effects of temperature on bare material or unwelded structure of Al-Mg-Si are well recognised. Yet, when it involves a welded or joined structure, the behaviour and performance due to the influence of alloying element such as $\mathrm{Mg}$ from filler addition on the growth and morphology of oxide formation were absolutely dissimilar. Moreover, lack of research was carried out involving welded $6061 \mathrm{Al}$ alloy structure $[15,16]$. Furthermore, the oxidation process may be more complex for welded parts composed of alloys with different oxide growth rates because of geometric and microstructural differences between the parent and fused parts. Al alloys have been reported to exhibit poor resistance to high temperature oxidation, especially in the region of the welded joint [17]. A study by Maggiolino and Schmid [18] showed that at temperature greater than $500{ }^{\circ} \mathrm{C}$, oxide formation on the surface of most 6000 -series $\mathrm{Al}$ alloys leads to significant mass gain causing metal loss and degradation of its mechanical properties $[19,20]$. Additionally, the nature, composition, structure, and thickness of the oxide depend on the environmental conditions and alloy composition [18, 21]. Frolish et al. [21] reported that the oxide layer formed on $\mathrm{Al}$ alloys is more tenacious, leads to intermixing of the surface metal and oxide layer and creates an intricate subsurface layer. Magnesium is a common element in $\mathrm{Al}$ alloys that has high affinity for oxygen and is principally prone to surface degradation during manufacturing stages that require high temperature services; for example, welding or heat treatment [22-24]. Van Agterveld et al. [2] reported that an Al-Mg alloy exposed up to $400{ }^{\circ} \mathrm{C}$ in an air circulation furnace formed a surface oxide layer largely consisting of $\mathrm{MgO}$. As reported in Cheng et al. [25], the evolution of surface oxide for the alloy with $\mathrm{Mg}$ content below $2.0 \mathrm{wt} \%$ during brazing process was found to be dissimilar. The enrichment of $\mathrm{Mg}$ element was not detected while the oxide surface was found to be covered with $\mathrm{Al}_{2} \mathrm{O}_{3}$. It was indicated that the oxide film grew obviously and the thickness would be more than before reaching $80 \mathrm{~nm}$. Meanwhile, it was reported that when $\mathrm{Mg}$ content was above $2.0 \mathrm{wt} \%$, its element was significantly enriched on the outermost surface of the alloy and mixed with $\mathrm{MgAl}_{2} \mathrm{O}_{4}$ and the thickness increased to $130 \mathrm{~nm}[25,26]$. Therefore, it is significant to note that each alloying element plays its own role in order to decide its oxidation performance whether on the surface or subsurface of the alloy. It is important to distinguish the role of the element since the content can clearly show significant differences in oxidation behaviour. In addition, the 
most important issue is how the concentrations of this second major element change on the metal surface and subsurface zone during oxidation although it is always more clearly affected at the external surface. Thus, this study focuses on the oxide layer formed on parent and fused metal parts made from AA6061 using Al-5\% Mg (ER5356) filler metal when subjected to high-temperature oxidation. The growth patterns, morphologies, and phases of the oxides formed at 400,500 and $600{ }^{\circ} \mathrm{C}$ were investigated.

\section{METHODS AND MATERIALS}

Samples used were welded $6061 \mathrm{Al}$ alloy parts for high-temperature oxidation experiments. These parts were prepared using gas metal arc welding (GMAW) at $25 \mathrm{~V}$ and 185A using commercially available ER5356 filler metal. Table 1 presents the chemical compositions of the filler and base metals carried out using spectrometer arc method. Table 2 shows the welding parameters used to join the AA6061 alloy plates. The welding work was carried out manually at UNIKL MFI welding workshop by a certified welder.

Table 1. Chemical composition in wt $\%$ of base metal, AA6061 Al alloy and filler metal ER5356.

\begin{tabular}{cccccccccc}
\hline & $\mathrm{Si}$ & $\mathrm{Fe}$ & $\mathrm{Cu}$ & $\mathrm{Mn}$ & $\mathrm{Mg}$ & $\mathrm{Cr}$ & $\mathrm{Zn}$ & $\mathrm{Ti}$ & $\mathrm{Al}$ \\
\hline AA6061 & 0.8 & 0.7 & 0.4 & 0.15 & 1.2 & 0.35 & 0.25 & 0.15 & 96.10 \\
ER 5356 & 0.27 & 0.40 & 0.10 & 0.10 & 5.00 & - & - & - & 94.13 \\
\hline
\end{tabular}

Table 2. Welding parameters used to weld AA6061 Al alloy.

\begin{tabular}{lc}
\hline \multicolumn{1}{c}{ Welding Parameter } & Description \\
\hline Diameter filler wire ER5356 & $1.00 \mathrm{~mm}$ \\
Polarity & Direct current reverse polarity \\
Amperage & $185 \mathrm{~A}$ \\
Voltage & $25 \mathrm{~V}$ \\
Travelling speed & $400 \mathrm{~mm} / \mathrm{min}$ \\
Heat input & $0.75 \pm 0.08 \mathrm{KJ} / \mathrm{mm}$ \\
Shielding Gas & Argon \\
\hline
\end{tabular}

The $6061 \mathrm{Al}$ alloy plates with original dimensions of $300 \mathrm{~mm}$ (length) $\times 200 \mathrm{~mm}$ (width) $\times 12 \mathrm{~mm}$ (thickness) were hand cut and designed with double-V groove butt joints. After welding the plates, the bead contour, bead appearance, and weld quality were inspected visually to identify any discontinuities of the fused metal region. Samples with dimensions of $60 \mathrm{~mm} \times 10 \mathrm{~mm} \times 5 \mathrm{~mm}$ were then cut from the welded plate with each sample contained parent and fused metal regions. The samples were mechanically ground using silicon carbide paper and polished subsequently with $3 \mu \mathrm{m}$ and $1 \mu \mathrm{m}$ diamond paste. These samples were then subjected to high-temperature oxidation tests. The oxidation tests were carried out in laboratory-type air-circulated horizontal tube furnace at $400{ }^{\circ} \mathrm{C}$, $500{ }^{\circ} \mathrm{C}$, and $600{ }^{\circ} \mathrm{C}$ in an air atmosphere for $40 \mathrm{~h}$ followed by slow cooling at $1.5^{\circ} \mathrm{C}$ $\min ^{-1}$. The oxidised samples were characterised using a scanning electron microscope (SEM, LEO 1450) equipped with an energy-dispersive X-ray spectroscopy (EDS) unit to 
obtain the oxide layer morphology, cross-sectional images, and constituent elements present. Phase identification was carried out using an X-ray diffractometer (XRD, Bruker AXS:D8 Advance model).

\section{RESULTS AND DISCUSSION}

\section{Oxide Characteristics}

Figure 1 shows the oxide scale formed on the welded part of the AA6061 Al alloy after oxidation at $400{ }^{\circ} \mathrm{C}, 500{ }^{\circ} \mathrm{C}$, and $600{ }^{\circ} \mathrm{C}$ for $40 \mathrm{~h}$. It was found that the colour of the welded sample, especially in fused metal part turned from the metallic-like appearance to gray colour with dark patches at $400{ }^{\circ} \mathrm{C}$ (Figure 1(a)), dark grey at $500{ }^{\circ} \mathrm{C}$ (Figure $1(\mathrm{~b})$ ), and finally greyish black at $600{ }^{\circ} \mathrm{C}$ (Figure 1(c)) as the impact of increasing oxidation temperature. From the results, it clearly implies that the oxidation temperature has a strong consequence on the exterior appearance and oxidation behaviour. It was also suggested by $[2,27,28]$ that the rough outermost surface layer of $\mathrm{Al}$ after oxidation exposure indicated a formation of a thin oxide layer and it was believed that this layer was mostly a porous structure. Further prolong exposure to high temperature led to the deposition of oxides mainly on the surface area of Al alloy. It was found that the oxides grew unevenly over the metal surface area and this finding was consistent with the increase of temperature.
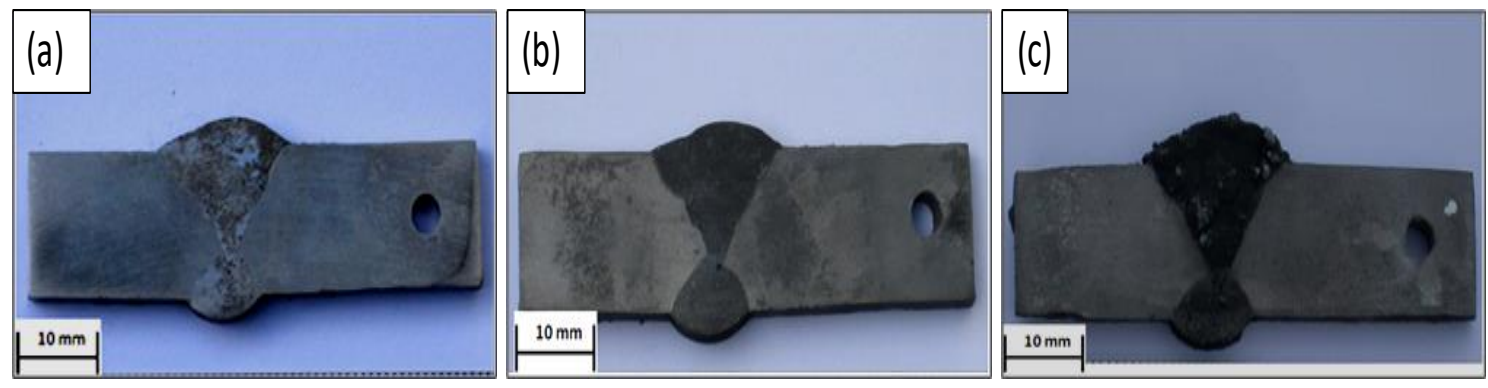

Figure 1. Optical images of oxidised welded samples for $40 \mathrm{~h}$ at (a) $400{ }^{\circ} \mathrm{C}$, (b) $500{ }^{\circ} \mathrm{C}$, and (c) $600{ }^{\circ} \mathrm{C}$.

Figures 2 and 3 show the surface morphologies of the oxidised parent and fused metal regions, respectively. The parent metal (Figures 2 (a-c)) has uniform and more compact oxides compared to fused metal surfaces (Figures 3 (a-c)). The oxide formed on the parent metal surface was likely more protective than the oxide formed on the fused metal surface. As reported in [26, 29], the oxide formed on fused metal part resulted from the combination of high temperature oxidation and internal degradation from previous welding procedure. The porous surface texture was found to act as a quick channel for oxidation to take place. Thus, the fused metal might have an internal degradation at a very rapid rate. The morphology of the parent metal surface showed that the oxide formed was compact with less oxidation attack even when oxidised at $600{ }^{\circ} \mathrm{C}$. Meanwhile, it was found that the surface with less oxidation attack existed on the fused metal part oxidised at $400{ }^{\circ} \mathrm{C}$ (Figure $3(\mathrm{a})$ ), and then after oxidation was set at $500{ }^{\circ} \mathrm{C}$, the fused metal surface yielded a nodular feature with typical cauliflower-like morphology as indicated in Figure 3(b). As the temperature continuously set to $600{ }^{\circ} \mathrm{C}$, the fused metal surface was found to be distributed by a mixture of nodular and flake-like white grains (Figure 3 (c)), which eventually indicate that the colour changed from the greyish black nodular oxides 
to white flake-like oxides. This result indicates that the parent and fused metal regions have different oxidation mechanisms and produce different oxide morphologies for both surface and subsurface sample. The compact morphology of the alloy surface reduced oxygen penetration through the oxide layer to the alloy / oxide interface, which slowed down the oxide growth. However, the oxide tended to agglomerate and thus exfoliate when being exposed for longer times and at higher temperatures. It is in agreement with [30-32] that raising the temperature further resulted in rapid oxidation degradation and instead of surface texture, the rates of mass increase changed proportionally with temperature. Meanwhile, the growth of oxide is a spontaneous process and it is accepted that as the temperature increases, the movement of atoms becomes violent as the oxidation temperature is higher. Thus, this will deteriorate the perfect surface texture leaving the surface more porous compared to earlier smooth structure [20,33].
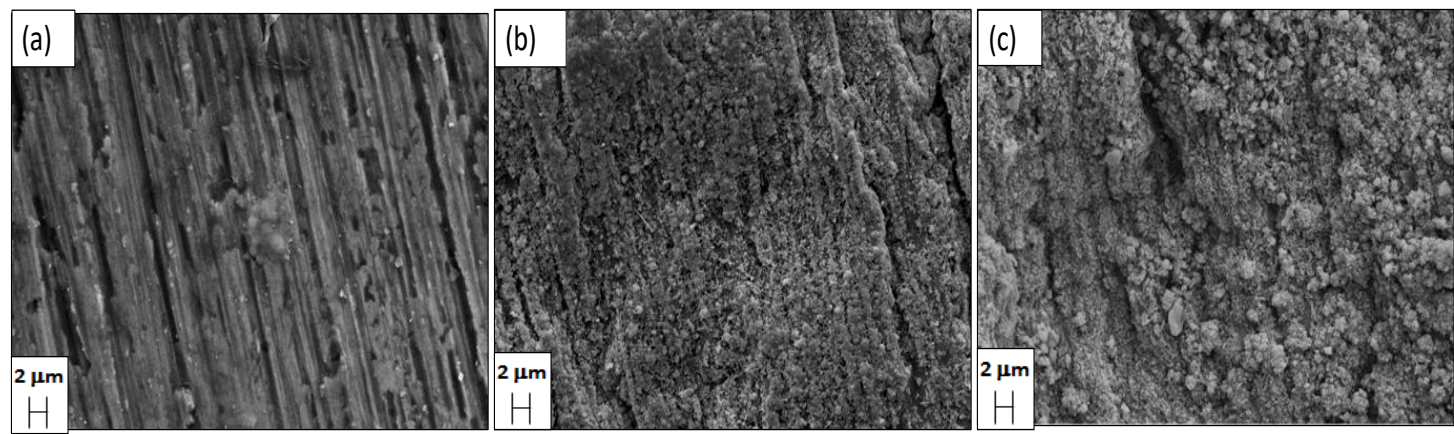

Figure 2. SEM images of surface oxide morphology of parent metal AA $6061 \mathrm{Al}$ alloy oxidised for $40 \mathrm{~h}$ at (a) $400{ }^{\circ} \mathrm{C}$, (b) $500{ }^{\circ} \mathrm{C}$, and (c) $600{ }^{\circ} \mathrm{C}$.
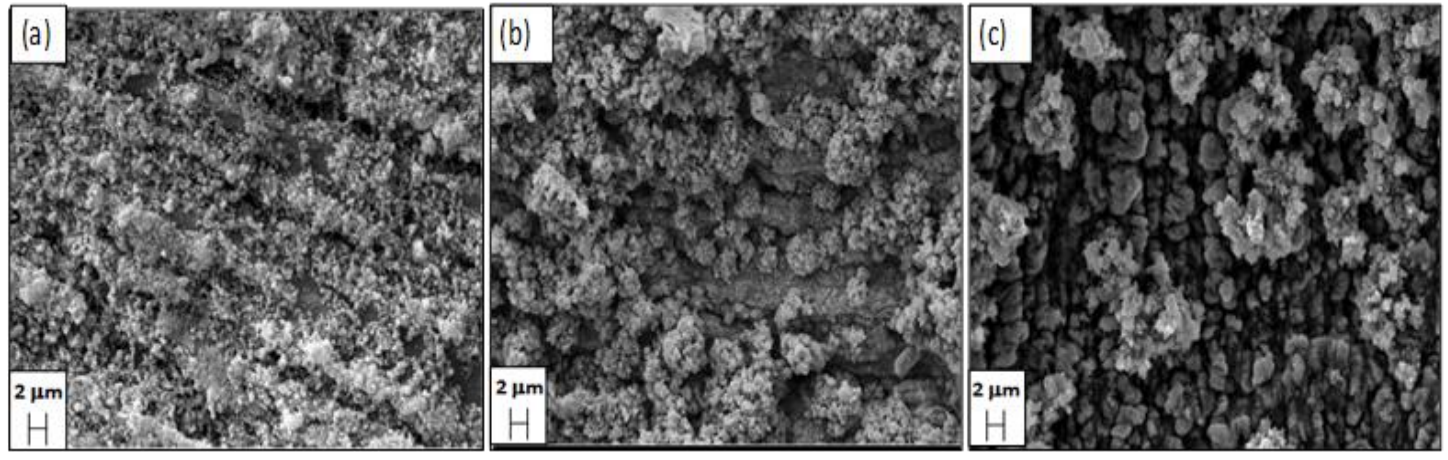

Figure 3. SEM images of surface oxide morphology of fused metal AA $6061 \mathrm{Al}$ alloy oxidised for $40 \mathrm{~h}$ at (a) $400{ }^{\circ} \mathrm{C}$, (b) $500{ }^{\circ} \mathrm{C}$, and (c) $600{ }^{\circ} \mathrm{C}$.

\section{Cross-sectional Analysis}

SEM analysis was performed for a correlation between heating temperature with the oxidation behaviour of welded $6061 \mathrm{Al}$ alloy at parent and fused metal regions. Figure 4 illustrates the SEM cross-section images of the oxide layers formed on the surface of parent metal after oxidation at 400,500 , and $600{ }^{\circ} \mathrm{C}$ for $40 \mathrm{~h}$. It shows that as the temperature increased, the internal subsurface oxide particles were found to be accumulated. It is clearly shown that no visible growth of external layers was found on top of the parent metal surface. In this region, the accumulation of oxide particles is also known as oxide enrichment that contains $\mathrm{Mg}$ and Si resulted from diffusion of oxygen. Thus, it leads to an inward oxide growth. It is suggested that during the internal oxide 
growth, oxygen must diffuse through developed external oxide layers and dissolve in the metallic matrix. The rate of this oxide growth may be controlled by oxygen diffusion, alloy element diffusion or both [19, 25, 34].
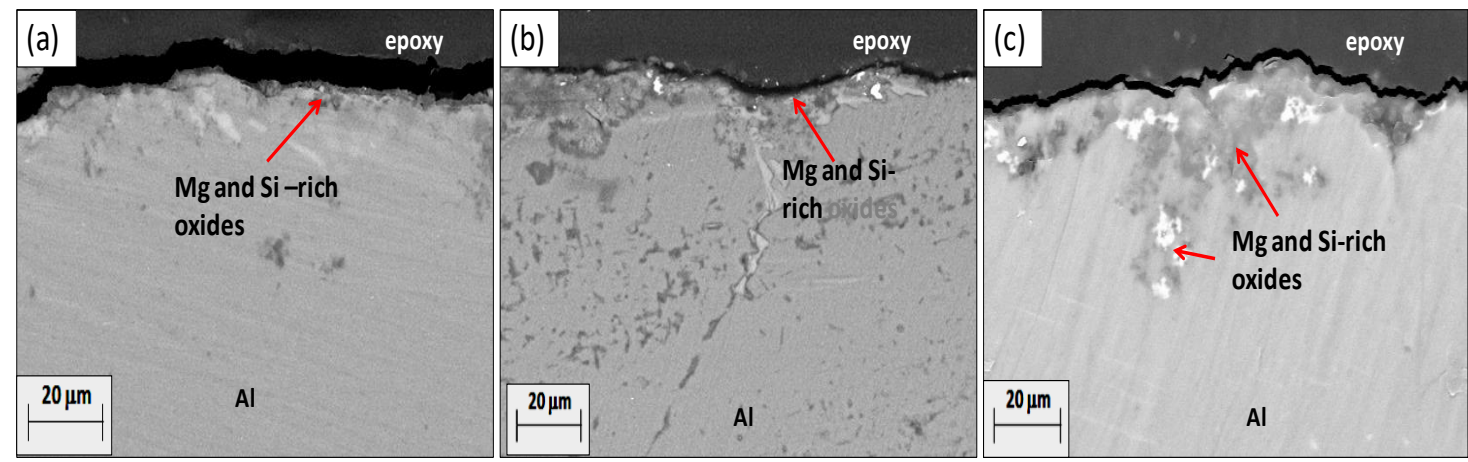

Figure 4. A cross-sectional SEM images of parent metal part of welded $6061 \mathrm{Al}$ alloy oxidised at (a) $400{ }^{\circ} \mathrm{C}$, (b) $500{ }^{\circ} \mathrm{C}$, and (c) $600{ }^{\circ} \mathrm{C}$ for $40 \mathrm{~h}$.
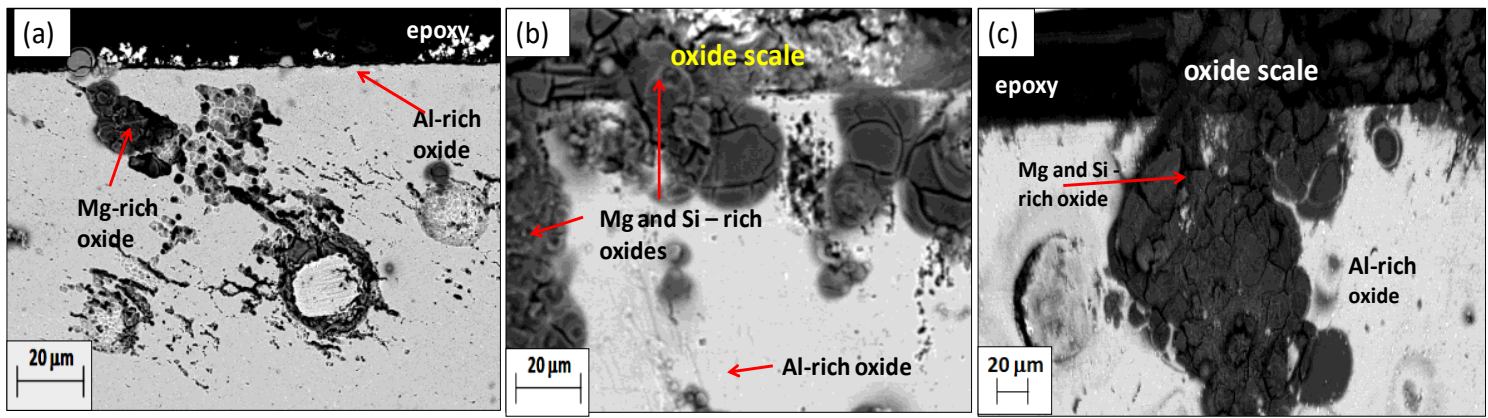

Figure 5. A cross-sectional SEM images of fused metal part of welded $6061 \mathrm{Al}$ alloy oxidised at (a) $400{ }^{\circ} \mathrm{C}$, (b) $500{ }^{\circ} \mathrm{C}$, and (c) $600{ }^{\circ} \mathrm{C}$ for $40 \mathrm{~h}$.

Meanwhile, Figure 5 indicates the results of fused metal part. Based on both figures, it is visibly shown that the degree of the surface and subsurface degradations of the samples tend to increase when the oxidation temperature increases. As the temperature increased, the growth of external layers became visible. In this case, the growth of external layers was controlled by the metal diffusion which led to an outward oxide growth [22, 32]. Meanwhile, a thin protective oxide layer was formed on parent metal part after oxidation exposure at 400, 500 and $600{ }^{\circ} \mathrm{C}$ (Figure 4). As the temperature increased, internal diffusion of oxygen ions become more dominant and the subsequent of oxidation reaction took place leading to the formation of internal oxidation. It is emphasised that an internal oxidation resulted when alloy element was selectively oxidised and in other words, the diffused metal cannot reach the surface quickly to develop external scale [30]. When oxygen penetrates the metal subsurface, dissolves in an alloy, and reacts to solute metal, dispersed precipitates of metal oxides were formed as shown in Figures 4 (a-c) and 5 (a-c) [35]. In addition, in some cases or conditions, the internal oxidation and external layer or scale development can occur simultaneously. Meanwhile, contradicted observation was shown for the fused metal part. It shows that by extending the oxidation temperature from 400 (Figure 5 (a)) to $500{ }^{\circ} \mathrm{C}$ (Figure 5 (b)), severe internal oxide attack was discovered within the substrate which specified the 
internal degradation caused by oxidation [27, 31]. Moreover, the outer oxide scale seemed to be thickened. As the temperature was set to $600{ }^{\circ} \mathrm{C}$, the condition became worse causing agglomerated oxide scale to occur on the surface and sub surface of the fused metal substrate (Figure 5(c)) [37]. This is because the porous oxide layer developed on the surface of the fused metal cannot inhibit oxygen from further penetrating into the oxide surface and reacting with element $[35,36]$. In this case, it is referred to $\mathrm{Mg}$ due to the non-protective and porous structure $[10,12,14]$. Thus, causing internal oxidation to occur in the substrate, especially at the part where stress raiser is high and contains pores, cracks, and voids resulting from previous sample preparation and welding process. It also acts as a short circuit pathway where the movement of oxygen ions becomes faster and thus causes the more prominent internal oxidation [37-39]. It is interesting to note that when the oxidation temperature increased, the oxidation process continued and more complex oxidation behaviour occurred which made the porous oxide layer thickened and internal degradation was prominently found. This also causes the formation of internal phase dissolution and precipitation. By raising the oxidation temperature to 500 and 600 ${ }^{\circ} \mathrm{C}$ (Figure 5), a thicker and more porous oxide scale containing microstructural defects such as pores and cracks as it worked as a short circuit path and thus, assisted the process of outward diffusion of metal ion such as $\mathrm{Mg}$. Therefore, more voids were produced at the alloy-oxide interface resulting from $\mathrm{Mg}$ transportation.

Table 3. The possible chemical reaction and standard Gibbs free energies during oxidation at $400{ }^{\circ} \mathrm{C}$ and $600{ }^{\circ} \mathrm{C}$.

\begin{tabular}{lcccc}
\hline Reaction & $\begin{array}{c}-\Delta \mathrm{H} \\
(\mathrm{J} / \mathrm{g} . \mathrm{mole})\end{array}$ & $\begin{array}{c}-\Delta \mathrm{S}(\mathrm{J} / \mathrm{g} . \mathrm{mole} . \\
\left.{ }^{\circ} \mathrm{K}\right)\end{array}$ & $\begin{array}{c}\Delta \mathrm{G}^{\mathrm{o}} 400 \\
(\mathrm{~kJ})\end{array}$ & $\begin{array}{c}\Delta \mathrm{G}^{\mathrm{o}} 600 \\
(\mathrm{~kJ})\end{array}$ \\
\hline $2 \mathrm{Mg}+\mathrm{O}_{2}(\mathrm{~g}) \rightarrow 2 \mathrm{MgO}$ & $1,219,140$ & 233.04 & $-1,062.30$ & $-1,015.68$ \\
& & & & \\
\hline $4 / 3 \mathrm{Al}+\mathrm{O}_{2}(\mathrm{~g}) \rightarrow 2 / 3$ & $1,121,922$ & 215.47 & -976.91 & -931.66 \\
$\mathrm{Al}_{2} \mathrm{O}_{3}$ & & & & \\
\hline
\end{tabular}

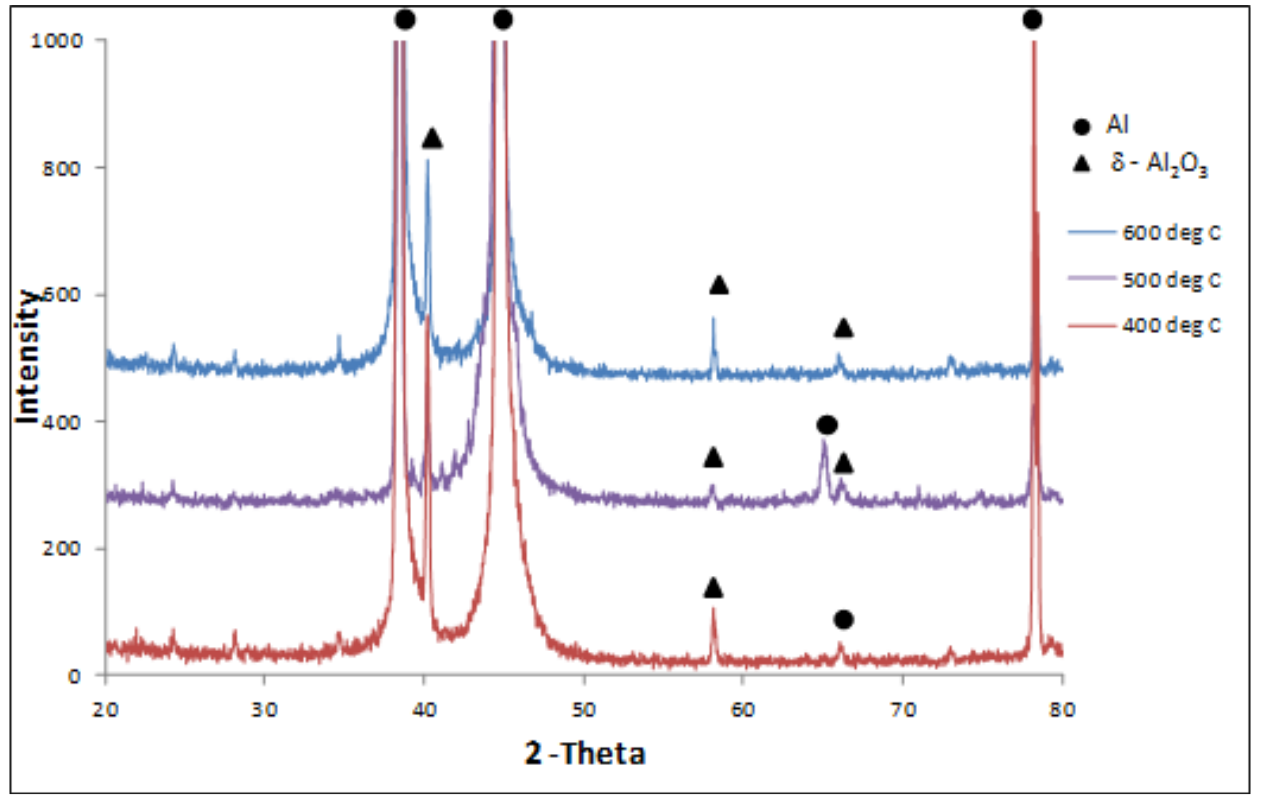

Figure 6. XRD diffractograms of parent metal part in welded $6061 \mathrm{Al}$ alloy oxidised for $40 \mathrm{~h}$ at (a) $400{ }^{\circ} \mathrm{C}$, (b) $500{ }^{\circ} \mathrm{C}$, and (c) $600{ }^{\circ} \mathrm{C}$. 
Table 3 shows the possible chemical reaction and standard Gibbs free energy during oxidation at $400{ }^{\circ} \mathrm{C}$ and $600{ }^{\circ} \mathrm{C}$. The $\Delta \mathrm{G}^{\circ}{ }_{400}$ and $\Delta \mathrm{G}^{\circ}{ }_{600}$ for the formation of $\mathrm{MgO}$ at $400{ }^{\circ} \mathrm{C}$ and $600{ }^{\circ} \mathrm{C}$ using $1 \mathrm{~mol}$ of $\mathrm{O}_{2}$ were equal to $-1,062.30$ and $-1,015.68 \mathrm{~kJ}$, respectively, which was lower than $\mathrm{Al}_{2} \mathrm{O}_{3}(-931.66 \mathrm{~kJ})$. Therefore, it is suggested that the oxidation reaction is possible to take place at a temperature of $400{ }^{\circ} \mathrm{C}$ and $600{ }^{\circ} \mathrm{C}$.

Figures 6 and 7 show XRD results revealing that $\delta-\mathrm{Al}_{2} \mathrm{O}_{3}$ was present in both figures instead of $\mathrm{Al}$, especially in parent metal part. As indicated in Figure 7, $\gamma-\mathrm{Al}_{2} \mathrm{O}_{3}$ and $\mathrm{MgO}$ were found in the fused metal part, especially for those oxidised at $500{ }^{\circ} \mathrm{C}$ and $600{ }^{\circ} \mathrm{C}$. At $600{ }^{\circ} \mathrm{C}$, Mg-rich oxides are more prevalent because of the higher diffusion rate of both $\mathrm{Mg}^{2+}$ and $\mathrm{Al}^{3+}$ into $\mathrm{Al}_{2} \mathrm{O}_{3}$ and $\mathrm{MgO}$, respectively. As reported earlier, a uniform and compact oxide was formed when the parent metal part oxidised at $600{ }^{\circ} \mathrm{C}$, whereas a porous oxide was formed on the fused metal as shown in Figures 4 and 5. These differing oxide morphologies were caused by different oxidation mechanisms because the parent and fused metals have different chemical compositions. The morphology of the thin oxide scale on the fused metal (Figure 3) was absolutely temperature-dependent. In further reaction, the coalesced oxide nodules led to a continuous fine-grained nonprotective scale with a loose surface texture, especially in the fused metal region. Because the welded joint has a complex microstructure with variation of phases, the oxidation mechanisms in the fused metal region were intricate, involving several surface reactions and forming many phases $[33,40]$. Thus, the oxide scale on the fused metal became porous and non-protective, offering no resistance to continuing oxidation. Because of the porous structure, oxygen can easily penetrate the oxide scale, and thus increase the oxidation behaviour.

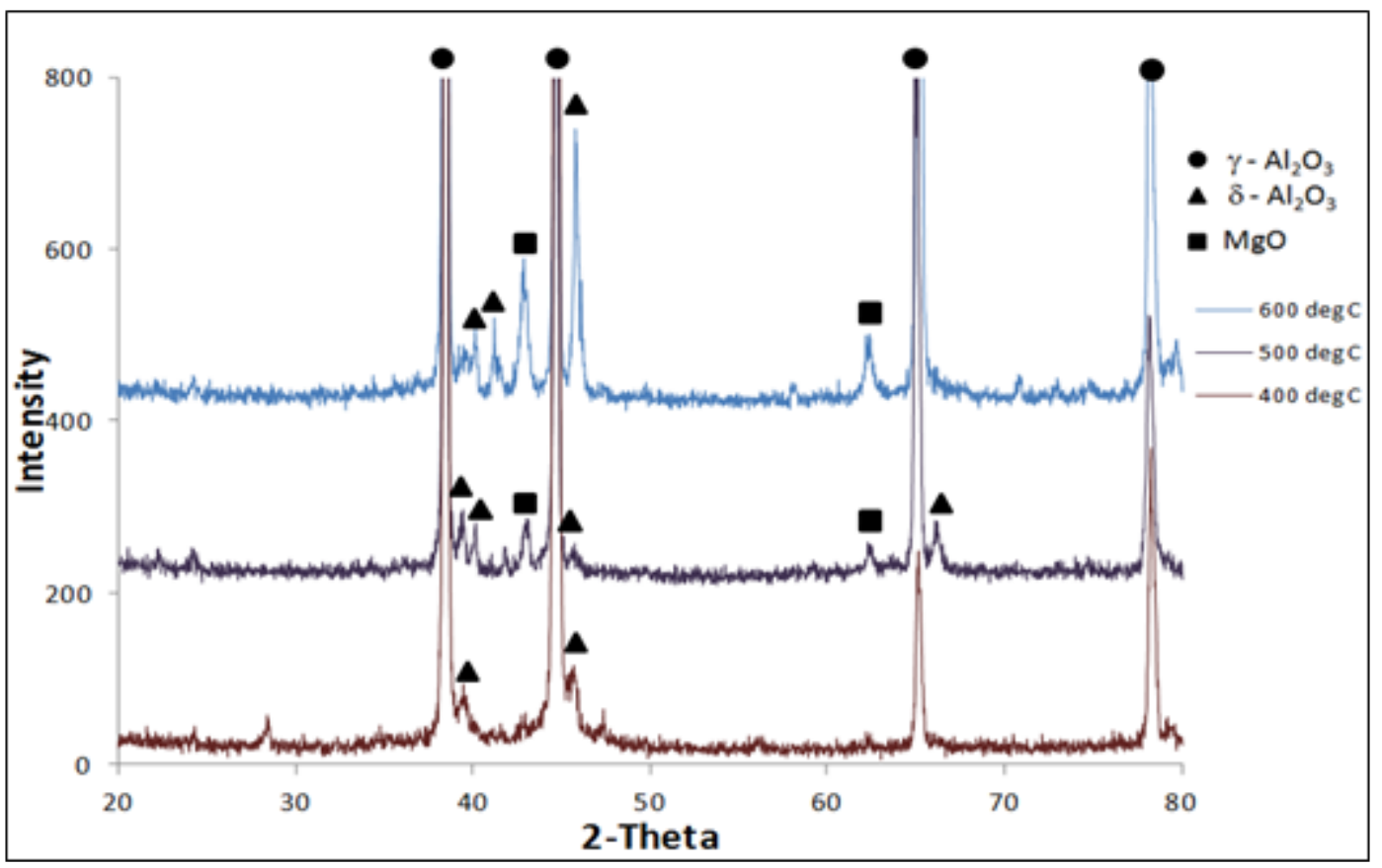

Figure 7. XRD diffractograms of a fused metal part in welded $6061 \mathrm{Al}$ alloy oxidised for $40 \mathrm{~h}$ at (a) $400{ }^{\circ} \mathrm{C}$, (b) $500{ }^{\circ} \mathrm{C}$, and (c) $600{ }^{\circ} \mathrm{C}$.

Particularly, the welded joint contained a unique area between the fused and nonfused base metal known as fusion boundary. The fusion boundary is an important area to 
consider due to the degradation which usually begins there. Generally, all phase compositions within the fusion boundary are mixtures of the filler and base metal alloys $[41,42]$. Pure metals and alloys are not stable, especially when exposed to hightemperature oxidation. For a welded joint, the combination of temperature, oxidation environment, and contaminants from previous welding procedure can cause rapid internal degradation $[43,44]$. Porosity defects in the fused metal also increase oxygen penetration, which in turn act as a channel that accelerates oxidation [45, 46]. Defects caused by welding and sample preparation are important in the oxidation process because porosity and voids can raise the rate of oxygen penetration all the way through the welded alloy surface. Thus, it is suggested that the differences of oxide morphology in both parent and fused metal lead to a different oxide growth in the welded joint showing the effect of temperature-dependent when it is subjected to high-temperature environment.

\section{CONCLUSIONS}

The welded $\mathrm{Al}$ alloy studied in the present work showed less oxidation attack at $400{ }^{\circ} \mathrm{C}$ and poor oxidation behaviour at 500 and $600{ }^{\circ} \mathrm{C}$. Further prolong exposure to high temperature leads to the deposition of oxides mainly in the surface area of parent metal part. Meanwhile, as the temperature increased, internal subsurface oxide particles were found to be accumulated. The $\delta-\mathrm{Al}_{2} \mathrm{O}_{3}$ phase was detected in both parent and fused metal samples after being exposed to oxidation at 400, 500 and $600{ }^{\circ} \mathrm{C}$. Contradicted observation showed that the $\mathrm{MgO}$ phase was detected in fused metal part responsible for the poor oxidation behaviour. Moreover, the morphological differences indicated that the behaviour of protective oxide formed on the parent metal, while the non-protective was confirmed to dominate on the fused metal surfaces. Thus, it is recommended that the 6061 welded structure can withstand at $400{ }^{\circ} \mathrm{C}$ for long period in the air without serious deterioration but could not withstand exposure at 500 and $600{ }^{\circ} \mathrm{C}$ conditions in air.

\section{ACKNOWLEDGEMENTS}

The authors would like to be obliged to Universiti Kuala Lumpur Malaysia France Institute (UNIKL MFI) for providing laboratory facilities and financial assistance under project no. STR 15105 and STR 15019.

\section{REFERENCES}

[1] Andreatta F, Terryn H, de Wit JHW. Corrosion behaviour of different tempers of AA7075 aluminium alloy. Electrochimica Acta. 2004;49:2851-62.

[2] Van Agterveld DTL, Palasantzas G, De Hosson JTM. Magnesium surface segregation and oxidation in $\mathrm{Al}-\mathrm{Mg}$ alloys studied with local probe scanning Auger-scanning electron microscopy. Applied Surface Science. 1999;152:250-8.

[3] Shah LH, Mohamad UK, Yaakob KI, Razali AR, Ishak M. Lap joint dissimilar welding of aluminium AA6061 and galvanized iron using TIG welding. Journal of Mechanical Engineering and Sciences. 2016;10:1817-26.

[4] Hasan MM, Ishak M, Rejab MRM. A simplified design of clamping system and fixtures for friction stir welding of aluminium alloys. Journal of Mechanical Engineering and Sciences. 2015;9:1628-39. 
[5] Sathari NAA, Shah LH, Razali AR. Investigation of single-pass/double-pass techniques on friction stir welding of aluminium. Journal of Mechanical Engineering and Sciences. 2014;7:1053-61.

[6] Arslan E, Totik Y, Demirci EE, Vangolu Y, Alsaran A, Efeoglu I. High temperature wear behavior of aluminum oxide layers produced by AC micro arc xidation. Surface \& Coatings Technology. 2009;204:829-33.

[7] Eskin DG, Massardier V, Merle P. A study of high-temperature precipitation in Al-Mg-Si alloys with an excess of silicon. Journal of Materials Science. 1999;34:811-20.

[8] Odusote JK, Adeleke AA, Ajayi PA. Mechanical properties and microstructure of precipitation-hardened $\mathrm{Al}-\mathrm{Cu}-\mathrm{Zn}$ alloys. International Journal of Automotive and Mechanical Engineering. 2015;12:3033-42.

[9] Nafsin N, Rashed HMMA. Effects of copper and magnesium on phase formation modeling and mechanical behavior in $\mathrm{Al}-\mathrm{Cu}-\mathrm{Mg}$ alloys. International Journal of Automotive and Mechanical Engineering. 2013;8:1151-61.

[10] Sinebryukhov SL, Sodorova MV, Egorkin VS, Nedozorov PM, Ustinov AY, Volkova EF, et al. Protective oxide coatings on Mg-Mn-Ce, Mg-Zn-Zr, Mg-Al$\mathrm{Zn}-\mathrm{Mn}, \mathrm{Mg}-\mathrm{Zn}-\mathrm{Zr}-\mathrm{Y}$, and Mg-Zr-Nd magnesium-based alloys. Protection of Metals and Physical Chemistry of Surfaces. 2012;48:678-87.

[11] Kim K-S, Sung S-Y, Han B-S, Park J-C, Lee K-A. High-temperature, low-cycle fatigue behavior of an $\mathrm{Al}-\mathrm{Mg}-\mathrm{Si}$ based heat-resistant. Metals and Materials International. 2015;21:1000-5.

[12] Stadler F, Antrekowitsch H, Fragner W, Kaufmann H, Uggowitzer PJ. Effect of main alloying elements on strength of Al-Si foundry alloys at elevated temperatures. International Journal of Cast Metals Research. 2012;25:215-24.

[13] Helwig HM, Garcia-Moreno F, Banhart J. A study of $\mathrm{Mg}$ and $\mathrm{Cu}$ additions on the foaming behavior of Al-Si alloys. Journal of Materials Science. 2011:1-32.

[14] Rana RS, Purohit R, Das S. Reviews on the Influences of alloying element on the microstructure and mechanical properties of aluminium alloys and aluminium alloy composite. International Journal of Scientific and Research Publication. 2012;2:1-7.

[15] Ishak M, Amir A, Hadi A. Effect of solution treatment temperature on microstructure and mechanical properties of A356 alloy. International Conference on Mechanical Engineering Research (ICMER 2013). Bukit Gambang Resort City, Kuantan, Pahang, Malaysia: Universiti Malaysia Pahang; 2013. p. 1-14.

[16] Ishak M, Mohd Noordin NF, Kamil Razali AS, Ahamd Shah LH. The effect of filler ER4043 and ER356 on weld metal structure of 6061 aluminium alloy by Metal Inert Gas (MIG). International Journal of Engineering Technology and Sciences. 2015;3:1-7.

[17] Palasantzas G, Van Agterveld DTL, De Hosson JTM. Electron beam induced oxidation of Al-Mg alloy surfaces. Applied Surface Science. 2002;191:266-72.

[18] Maggiolino S, Schmid C. Corrosion resistance in FSW and in MIG welding techniques of AA6XXX. Journal of Materials Processing Technology. 2008;197:237-40.

[19] Beck AF, Heine MA, Caule EJ, Pryor MJ. The kinetics of the oxidation of an Al in oxygen at high temperature. Corrosion science. 1967;7:1-22.

[20] Wood GC, Stott FH. Oxidation of alloys. Materials Science and Technology. 1987;3:529-30. 
[21] Frolish MF, Krzyzanowski M, Rainforth WM, Beynon JH. Oxide scale behaviour on aluminium and steel under hot working conditions. Journal of Materials Processing Technology. 2006;177:36-40.

[22] Czerwinski F. The early stage oxidation and evaporation of $\mathrm{Mg}-9 \% \mathrm{Al}-1 \% \mathrm{Zn}$ alloy. Corrosion Science. 2004;46:377-86.

[23] Mudali UK, Raj B. Corrosion science and technology. Mechanism, mitigation and monitoring. London: Alpha Science International Ltd; 2008.

[24] Reichel F, Jeurgens LPH, Mittemeijer EJ. The effect of substrate orientation on the kinetics of ultra-thin oxide-film growth on Al single crystals. Acta Materialia. 2008;56:2897-907.

[25] Cheng F, Zaho H, Wang Y, Xiao B, Yao J. Evolution of surface oxide film of typical aluminium alloy during medium-temperature brazing process. Transactions of Tianjin University. 2014;20:55-9.

[26] Jalar A, Lah NAC, Othman NK, Shamsudin R, Daud AR, Bakar SRS. Characterization of oxide growth on surface of Al-Mg-Si welded joint. Advanced in Materials Science and Engineering. 2014:1-10.

[27] Mikheev AY, Girn AV, Vakhteev EV, Alekseeva EG, Ravodina DV. The formation of a surface layer during microarc oxidation of aluminium alloys. Materials Science and Engineering. 2015;70:1-5.

[28] Nylund A, Mizuno K, Olegjord I. Influence of $\mathrm{Mg}$ and $\mathrm{Si}$ on the oxidation of aluminum. Oxidation of Metals. 1998;50:309-25.

[29] Muhamad Hellmy H, Nur Azida CL. An X-ray Photoelectron Spectroscopy Study On Oxidized Fusion Metal Part Of Welded 6061 Al Alloy. Jurnal Teknologi. 2017;79:1-17.

[30] Coker EN. The oxidation of aluminium at high temperature studied by Thermogravimetric analysis and Differential Scanning Calorimetry. Sandia Report. California: Sandia National Laboratories; 2013. p. 1-24.

[31] Shimizu K, Brown GM, Kobayashi K, Skeldon P, Thompsion GE, Wood GC. The early stages of high temperature oxidation of anAl-0.5 wt\% Mg alloy. Corrosion science. 1998;40:557-75.

[32] Tenorio JAS, Espinosa DCR. High temperature oxidation of Al-Mg Alloys. Oxidation of Metals. 2000;53:361-73.

[33] Arivazhagan N, Narayanan S, Singh S, Prakash S, Reddy GM. High temperature corrosion studies on friction welded low alloy steel and stainless steel in air and molten salt environment at 650 degrees C. Materials \& Design. 2012;34:459-68.

[34] Muhamad Hellmy H, Nur Azida CL. Cross-sectional analysis of oxidized fusion zone of welded AA6061 Al Alloy At High Temperature. In: International Conference Engineering Technology. Terengganu, Malaysia; 2015.

[35] Young J. Chapter 6 Oxidation of alloys II: Internal oxidation. Corrosion Series. 2008;1:247-314.

[36] Doilnitsyna VV. General diffusion-kinetic model of metallic oxidation. Corrosion science. 2002;44:1113-31.

[37] Venugopalan H, DebRoy T. Kinetics of directed oxidation of Al-Mg alloys into Al2O3 preforms. Materials Science and Engineering A. 1997;232:39-46.

[38] Nylund A, Mizuno K, Olegjord I. Influence of Mg and Si on the oxidation of aluminum. Oxidation of Metals. 1998;50:309-25.

[39] Doilnitsyna VV. General diffusion-kinetic model of metallic oxidation. Corrosion Science. 2002;44:1113-31. 
[40] Shimizu K, Brown GM, Kobayashi K, Skeldon P, Thompsion GE, Wood GC. The early stages of high temperature oxidation of anAl-0.5 wt\% Mg alloy. Corrosion Science. 1998;40:557-75.

[41] Othman NK, Bakar SRS, Jalar A, Syarif J, Ahmad MY. The effect of filler metals on mechanical properties of 6 mm AA 6061-T6 welded joints. In: Jiang ZY, Liu XH, Bu JL, editors. Materials Processing Technologies, Pts 1 and 22011. p. 8736.

[42] Bakar SRS, Ahmad MY, Ibrahim MFA, Jalar A, Djalil SJS, Othman NK. The effect of double pass GMAW process on microstructure and mechanical properties of AA 6061-T6 joining plates. In: Khan S, Salam IU, Ahmed K, editors. Advanced Materials Xii2012. p. 98-104.

[43] Chevalier S, Valot C, Bonnet G, Colson JC, Larpin JP. The reactive element effect on thermally grown chromia scale residual stress. Materials Science and Engineering a-Structural Materials Properties Microstructure and Processing. 2003;343:257-64.

[44] Kofstad P. High temperature corrosion. England Elsevier Applied Science; 1988.

[45] Tenorio JAS, Espinosa DCR. High temperature oxidation of Al-Mg Alloys. Oxidation of Metals. 2000;53:361-73.

[46] Aaron JM, Chan HM, Harmer MP, Abpamano M, Caram HS. A phenomenological description of the rate of the aluminum/oxygen reaction in the reaction-bonding of alumina. Journal of the European Ceramic Society. 2005;25:3413-25. 